\title{
SMALL-SIDED GAMES AS MEANS OF TECHNICAL-TACTICAL PREPARATION AND EVALUATION FOR JUNIOR HANDBALL PLAYERS
}

\author{
Cristina ROMILA ${ }^{1 *}$, Silvia TEODORESCU ${ }^{1}$ \\ ${ }^{1}$ National University of Physical Education and Sport, Faculty of Physical Education and Sport, Bucharest, \\ Romania \\ *Corresponding author: cristina.romila@yahoo.com
}

DOI: https://doi.org/10.51267/icpesk2020bp12

\begin{abstract}
Tactical training is a component of sports training through which technical procedures are highlighted and learned, and their level of improvement is observed during the game. The purpose of the research is to develop and implement a training model for the tactical training of junior III based on small-sided games with variable dimensions of the field using information from the analysis of the tactical content of official games. As a result, in the tactical training of juniors, we implemented means of training and tests organized in the form of training games where we followed the individual and collective tactical actions of the players. The games had different themes and were organized with small numbers of players: 2 against 2, 3 against 3, 4 against 4, 2 against 2 against 2, 3 against 3 against 3, and 4 against 4 against, on playing areas of different sizes. The indicators monitored during tests were also recorded during official matches. The research subjects are the female players of the Junior III women's team born in 2005 and younger from the ACS Sporting Ghimbav, participants in the National Junior III Championship in the 2019-2020 competitive year. The conclusions of the study provided useful information during the training process.
\end{abstract}

Keywords: tests, technical training, tactical training, handball, juniors.

\section{Introduction}

At the moment, the game of handball is a popular sport, which can be practiced both in free time and at a professional level; in one form or another, handball-specific skills can be found in the physical exercise of children, young people and/or adults.

To achieve performance in this sport, players can be conditioned by the following factors: anthropometric characteristics, level of motor skills, tactical strategy, psychological factors, nutrition, social factors, external environment, etc. (Wagner et al., 2014).

The game of handball is characterised as a collective game and is played in speed (Priklerová, 2018).

Recognizing talented athletes who can practice a particular sport is a difficult process. Handball is a complex sport that can last over 60 minutes, during which players perform movements such as jumping, running, various throwing techniques, all of this followed by lowintensity recovery periods (Ghobadi et al., 2013). Currently, talent identification programmes are based on players' anthropometric criteria. According to specialists, the coordination ability could be criterion for the selection of young talents (Serrien \& Baeyens, 2018).

Playing conditions constantly change during the handball game. The player who performs a goal throw is often disturbed by the opponent and needs to adapt to changing environmental conditions. (Urbán et al., 2015)

The main purpose of this game is to score as many goals as possible (Pic, 2018). 
It is found by specialists that, in international competitions, winning teams use technical and tactical actions to create opportunities to score using distance shots, breakthroughs to the goal by individual tactical actions, or decisive passes to the pivot or wings. Winning teams also apply active and controlled defence systems that help them win balls in defence, so they can initiate a counterattack and score more easily. Teams in the attack phase often use simple tactical decisions by overtaking or breakthroughs to perform a 6-meter goal throw. (Milanović et al., 2018)

When training athletes, specialists should transmit the player clear ideas about the game. Players should be able to apply the learned content in both the absence and presence of the opponent. In order to implement the game-related ideas, we need to know the methodological sequence of applying the acquired knowledge. We will graphically represent a way to apply the tactical content for the two phases of the game (Figure 1).

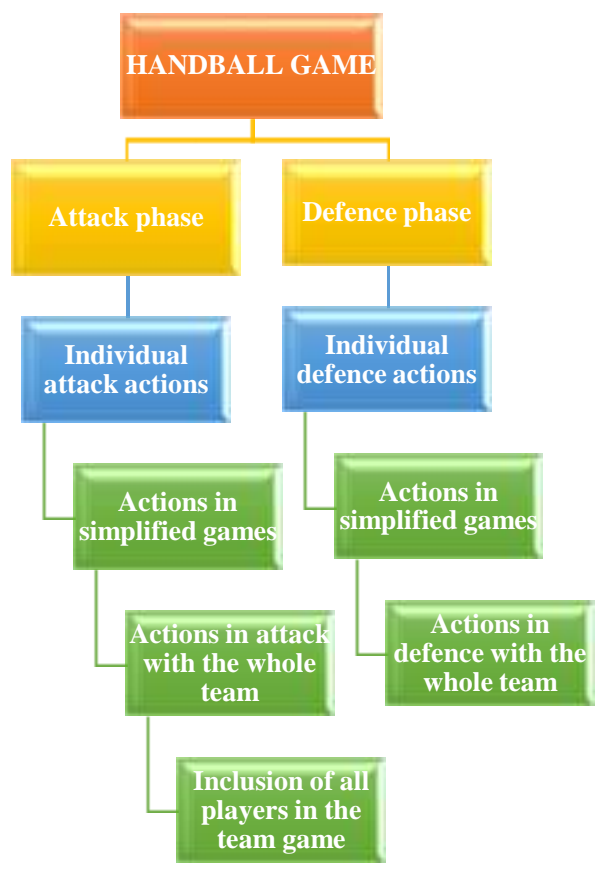

Figure 1. Graphical representation of the methodology of implementing the tactical content in a handball team (Sotiriu, 1998)

As can be seen in the figure above, after learning individual actions in the attack phase and the defence phase, they are programmed to be applied to small-sided games. It is known that one of the best ways to assess a team's knowledge and level of preparation is the game.

The use of the game as a means of training can be applied at different moments of training as follows: after learning some technical elements or tactical actions, "themed games" are planned, in which athletes have to apply the acquired knowledge; during the training and test periods, "training games" are used, and "friendly games" are planned in the pre-competition period when playing against other opponents (Hantău, 2017).

Small-sided games were taken over by experts as a method of implementing various technical and tactical actions in conditions of adversity for a better understanding of the game. According to specialists in the application of these games, players can thus better understand 
the tactical training. For example, in a football research (Gutiérrez et al., 2014) aimed at applying the game 5 against 5 players, the playing time was eight minutes, and the average age of children was 13 years. This study generated conclusions regarding the ability to understand and solve situations that arise during the match. Another football study (González-Víllora et al., 2013) tracked the effects of the small-sided game on different age groups: U8, 2 vs. 2 game; U10, 3 vs. 3 game; U12, 5 vs. 5 game; U14, 7 vs. 7 game. This study provides useful information for coaches on psychosocial issues such as overcoming egocentricity in the early stages of learning. Both mentioned studies used video means of recording the tactical actions performed by the players.

The Teaching Games for Understanding (TGfU) method is considered to be very useful in understanding the tactical training and implementation of the technical content. The implementation of the TGfU method has proven to be useful in improving players' ability to make timely decisions and using motor skills in different situations. (Hortiguela Alcalá \& Hernando Garijo, 2017)

Throughout the use of the game of handball as a means of preparation, specialists can observe the state of the team, its progress or regression, and can generate helpful conclusions to improve the game. Athletes can also self-evaluate in relation to their racing partners. Using the game as a means of preparation or evaluation is very important. During the game, specialists can follow the physiological and biomechanical variables of the players. (Wagner et al., 2016)

In order to get the victory in official matches, coaches must take into account the detailed actions of both their own team and the opposing team. It can be seen that, in all international competitions, there are many specialists who provide real-time information on team performance. This interest is observed to be increasing in all competitions, at junior and senior levels, but especially at the level of national teams. Specialists use different indicators based on which the factors that ensure team success in sports games can be determined (Bilge, 2012).

The analyses performed in order to establish the dynamic of the game, which is based on the cooperation of the whole team and the involvement of each player, highlight that it is very important for a handball player to choose the best solution to throw into the goal; many of the solutions found are the result of tactical combinations organized during the game (Korte \& Lames, 2019).

During the European Women's Handball Championship, at the last editions and not only, there are recordings of the games that bring together several indicators from the technical and tactical content of the handball game.

Table 1 shows the performance of the Romanian women's national teams participating in the last editions of the European Championship (EC). This table contains some of the indicators followed by specialists in the three competitions. 
Table 1. Performance of the Romanian women's national teams participating in the last editions of the European Championship

\begin{tabular}{|c|c|c|c|c|c|c|c|c|c|c|c|c|}
\hline \multirow{2}{*}{$\begin{array}{c}\text { Romanian } \\
\text { women's } \\
\text { national teams } \\
\end{array}$} & \multirow[t]{2}{*}{ Competition } & \multirow[t]{2}{*}{ Rank } & \multicolumn{7}{|c|}{ Attack phase } & \multicolumn{3}{|c|}{ Defence phase } \\
\hline & & & $\begin{array}{l}\text { Goal/ } \\
\text { Shots }\end{array}$ & $\%$ & As & $\mathrm{R} 7$ & TO & BT & $\mathrm{BS}$ & ST & AI & $\mathrm{P} 7$ \\
\hline Senior & $\begin{array}{c}\text { EC } 2018 \\
\text { France }\end{array}$ & 4 & $213 / 375$ & 57 & 76 & 36 & 52 & $19 / 23$ & 19 & 19 & - & 36 \\
\hline W19 & $\begin{array}{l}\text { EC } 2019 \\
\text { Hungary }\end{array}$ & 5 & $204 / 324$ & 63 & 109 & 22 & 77 & $47 / 61$ & 8 & 30 & 46 & - \\
\hline W17 & $\begin{array}{l}\text { EC } 2019 \\
\text { Slovenia }\end{array}$ & 11 & $188 / 289$ & 65 & 71 & 28 & 80 & $12 / 17$ & 8 & 26 & 121 & - \\
\hline
\end{tabular}

Through the example of records taken from the website of the European Handball Federation, we want to emphasise the importance of knowing these data as a basis for designing training and competition strategies. These statistical analyses appear from the first stages of the competition and are developed for each participating team (European Handball Federation, 2019a; European Handball Federation, 2019b; European Handball Federation, 2018).

We can consider this information as a necessity for knowing the evolution of each team since junior level; in order to collect as much relevant data as possible for an athlete/team, we think that small-sided games are the easiest and most efficient way to assess the performance behaviour of a junior player in conditions of adversity.

This is also confirmed by the literature data (Balint, 2005; Bota, 1984; Cercel, 1980; Cercel, 1983; Ghermănescu, 1983; Hantău, 2017; Igorov-Bosi et al., 2004), most specialists and theorists mentioning small-sided games as extremely valuable means of training.

In Romania, starting with the 2016-2017 competitive year, mini handball is played as a small-sided game. Each team is composed of 5 players. The rules used are simplified. The game system is 4 rounds, with 10 minutes for each half. In the first two halves, the team must apply the man-to-man defence system. (Federaţia Română de Handbal [Romanian Handball Federation], 2017)

\section{Premise and purpose}

In this paper, we aim to use small-sided games as a means of training and assessing the tactical knowledge of junior handball players. We believe that game simplification will lead all players to actively participate in solving tactical situations. In establishing the teams, their homogeneity regarding the tactical knowledge of the players was taken into account.

During games, the number of individual and collective tactical actions performed by the players in different situations/game tasks was tracked. The indicators followed during tests were then recorded during official matches too. 


\section{Methodology}

\section{Participants}

The research subjects are the female athletes of the Junior III women's team born in 2005 and younger from the ACS Sporting Ghimbav, participants in the National Junior III Championship in the 2019-2020 competitive year. The average age of the players is \pm 14 years, the number of players is 12, and their years of sports training are between 1 and 6 .

In order to carry out the research, the management of the ACS Sporting Ghimbav and the athletes' parents agreed to the informed consent.

\section{Procedure}

The training method used as a priority in this study was the Teaching Games for Understanding (TGfU), which was materialised in the use of small-sided games as a means of tactical training for the junior III team. The implementation of small-sided games as a means of evaluation provided useful information on the tactical content acquired by the players. For each test, an evaluation scale adapted to the players' level of knowledge was developed.

The tests were applied to the junior III female team. Thus, the first test took place on 17.09.2019 and 19.09.2019, respectively. The second test was performed on 19.11.2019, after the end of the 1st leg of the National Championship for the junior III category. After the matches played in geographical group F within the National Junior III Championship, the team recorded 16 victories and 6 defeats in the 22 matches played. The team qualified $3 \mathrm{rd}$ in the value group. A good result for the team, taking into account the experience of the players and the fact that most of them were young. We should mention that the playing time was different for athletes. Also, no match was identical to the others. What was similar in the playing style was that each team applied advanced defence systems in the first half.

The research used 6 means of training and evaluation in the form of small-sided games that had tactical actions in their content. The actions assessed through tests were also tracked and recorded during official matches.

Small-sided games consisted of:

a. 2 against $2(2 \times 2)$ game on a small field of $10 / 40 \mathrm{~m}$, time: $5 \mathrm{~min}$;

b. 3 against $3(3 \times 3)$ game on a small field of $15 / 40 \mathrm{~m}$, time: $7 \mathrm{~min}$;

c. 4 against 4 ( $4 \times 4)$ game on a regular playing field of 20/40 m, time: $10 \mathrm{~min}$;

d. 2 against 2 against $2(2 \times 2 \times 2)$ game on a small field of 10/40 m, time: 5 min;

e. 3 against 3 against $3(3 \times 3 \times 3)$ game on a small field of $15 / 40 \mathrm{~m}$, time: $7 \mathrm{~min}$;

f. 4 against 4 against $4(4 \times 4 \times 4)$ game on a regular playing field of 20/40 m, time: 10 $\min$.

\section{Description of small-sided games}

\section{a. $2 \times 2,3 \times 3,4 \times 4$ small-sided games}

Players are divided into groups of 2, 3 or 4 players. They must follow the rules of the game of handball and apply the learned technical procedures and tactical actions. The playing time 
is 5/7/10 minutes. Each player will be recorded by an evaluator, who can be a teacher or a player. The placement of players on the field will be as follows:

- In the 2 x 2 game - in the attack phase, left backcourt, right backcourt, and the other team in defence, half left and half right.

- In the 3 x 3 game - in the attack phase, left backcourt, right backcourt and centre backcourt, and the other team in defence, half left, half right and back centre. Players, depending on their playing position, can choose to play with a pivot instead of a centre backcourt.

- In the 4 x 4 game - in the attack phase, players can choose this formula: left backcourt, right backcourt, left wing and right wing or left backcourt, right backcourt, pivot and centre backcourt, and the other team in defence, half left, half right, far left and far right. Players can choose their placement according to their playing positions.

The coach will establish the groups so that team formations can be used. The defence system is advanced or in the area, and players can choose the defence system that they consider more advantageous, depending on their opponents and the defence systems used during matches. The playing area will be $10 / 40 \mathrm{~m}, 15 / 40 \mathrm{~m}, 20 / 40 \mathrm{~m}$. All attacks start with passes from the semicircle whether the player scores or not. All attacks begin with passes from the goalkeeper. If a phase is normally penalised with a 7-m throw, a 9-m throw will be awarded.

b. $2 \times 2 \times 2,3 \times 3 \times 3,4 \times 4 \times 4$ small-sided games

Players are divided into groups of 2, 3 or 4 players. The time of the test is 5, 7 or 10 minutes. The placement of players on the field will be as follows:

- In the 2 × 2 × 2 game - in the attack phase, left backcourt, right backcourt, and the other team in defence, half left and half right.

- In the $3 \times 3 \times 3$ game - in the attack phase, left backcourt, right backcourt and centre backcourt, and the other team in defence, half left, half right and back centre. Players, depending on their playing position, can choose to play with a pivot instead of a centre backcourt.

- In the $4 \times 4 \times 4$ game - in the attack phase, players can choose this formula: left backcourt, right backcourt, left wing and right wing or left backcourt, right backcourt, pivot and centre backcourt, and the other team in defence, half left, half right, far left and far right. Players can choose their placement according to their playing positions.

The defence system is advanced or in the area, and players can choose the defence system that they consider more advantageous, depending on their opponents and the defence systems used in official matches. The playing area will be 10/40 m, 15/40 m, 20/40 m.

Unlike the first tests, the teams are distributed in defence on both sides of the field and one in the centre of the field. The centre team starts to play in one of the halves of the field and, after scoring or losing the ball, the players remain in defence, and the defensive team becomes the one that will initiate the attack phase. After losing possession of the ball, the attacking team will apply the man-to-man defence system only in the centre of the field so that it can recover the ball from the opponent and initiate a new attack on the opposite side of the field. All attacks start with passes from the semicircle whether the player scores or not. All attacks begin with passes from the goalkeeper. If a phase is normally penalised with a 7-m throw, a 9-m throw will be awarded. 
We made the registration forms to evaluate the players' knowledge, and after that, their results. The indicators followed:

- in the attack phase: total goals scored, total goal shots preceded by an individual tactical action, total actions preceded by a collective tactical action, total counterattack actions; it should be mentioned that both actions in which goals were scored and missed as well as decisive passes were recorded;

- in defence: total number of balls recovered through an individual tactical action, total goals received in the defensive phase.

To evaluate the players, an evaluation scale was developed (Table 2). Each component of the attack and defence phases has a number of executions for each grade. The grades are: Insufficient (I), Enough (E), Good (G), Very Good (VG).

Table 2. Evaluation scale for small-sided games

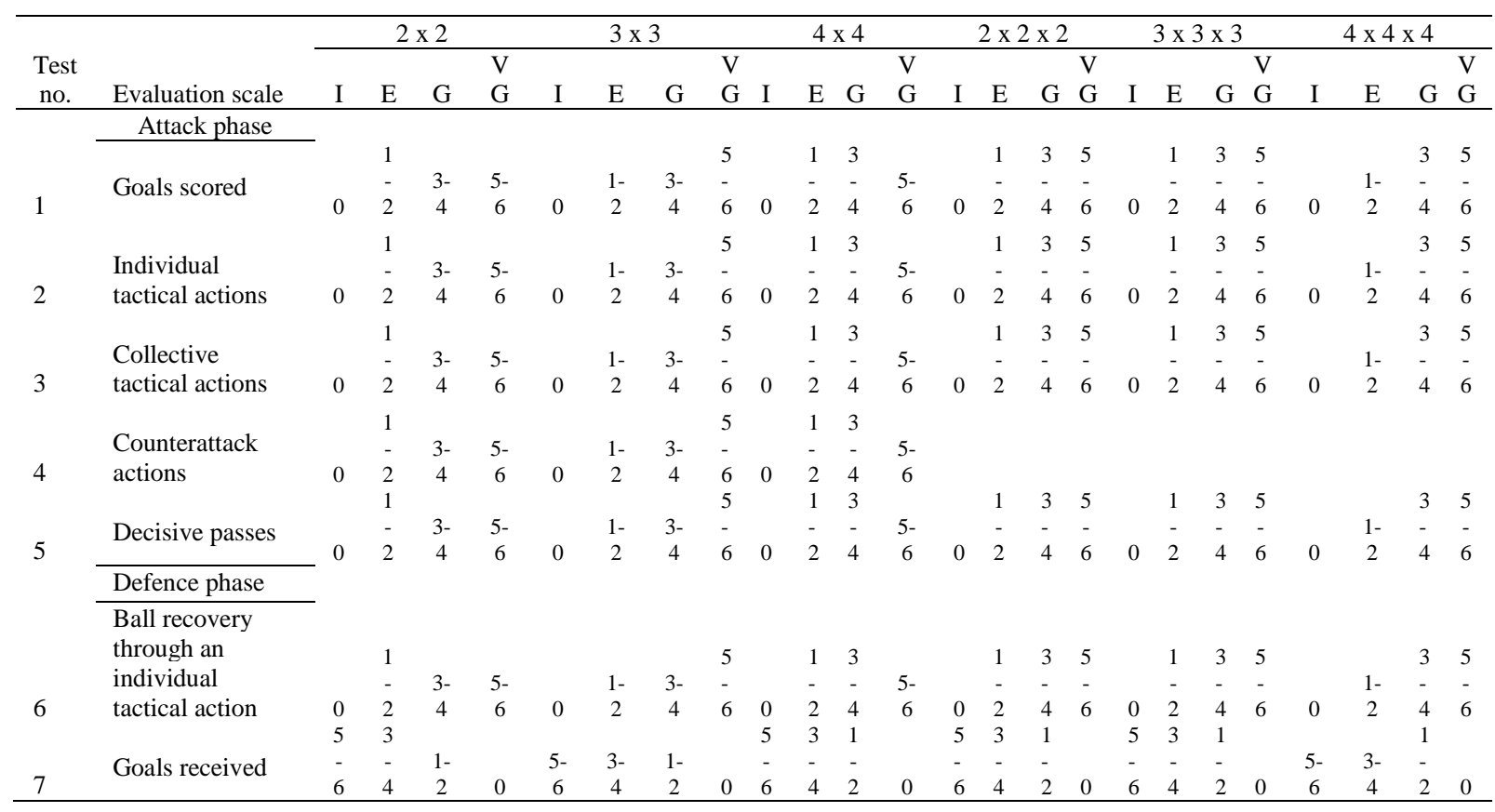

\section{Results}

Simplified games were used as a means of training and evaluation. Table 3 and Figure 2 show the number of training sessions in which small-sided games were implemented based on different themes from the technical or tactical content. It is also possible to observe the entire training period of the players from July 2019 to March 2020. During the sports training period, a total number of 128 training sessions were recorded, of which 20 contained small-sided games, 29 were official games and 18 were friendly games. 
Table 3. Distribution of training sessions containing small-sided games

\begin{tabular}{l|c|c|c|c|c|c}
\hline \multicolumn{1}{c}{ Month/Day } & No. TSG & P & OG & FG & No. TS-SG & TS-SG \\
\hline July & 17 & 8 & 0 & 0 & 6 & 0 \\
August & 10 & 3 & 6 & 12 & 3 & 0 \\
September & 10 & 13 & 3 & 0 & 2 & 2 \\
October & 10 & 11 & 4 & 3 & 3 & 0 \\
November & 9 & 14 & 4 & 1 & 2 & 1 \\
December & 9 & 18 & 4 & 0 & 0 & 0 \\
January & 11 & 16 & 2 & 0 & 1 & 0 \\
February & 10 & 12 & 4 & 2 & 1 & 0 \\
March & 3 & 26 & 2 & 0 & 0 & 0 \\
\hline
\end{tabular}

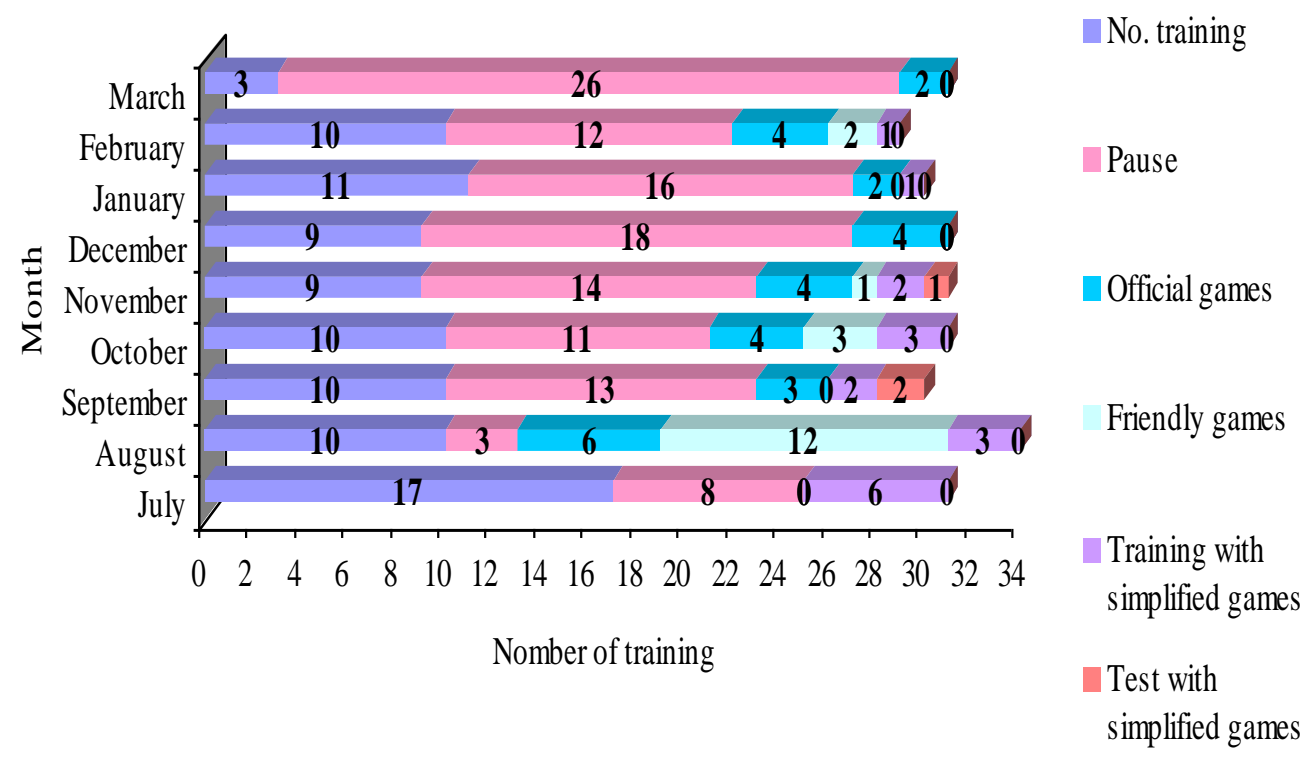

Figure 2. Graphical representation of the training period

We will present the results recorded by the players following the implementation of smallsided games as a means of evaluation, and the results recorded during official matches. For each indicator, we will present: tables with the recorded data, a model table representing the player evaluation according to the scale designed to measure player performance, tables with central tendency parameters, tables with significant correlations between indicators and in twolegged matches or initial/final tests. 
a. The "goals scored" indicator

Table 4. Total goals scored in the two-legged official matches in geographical groups of the National Junior Championship III and in tests

\begin{tabular}{|c|c|c|c|c|c|c|c|c|c|c|c|c|c|c|c|c|}
\hline \multirow[b]{4}{*}{ No. } & \multirow{4}{*}{$\begin{array}{l}\text { Name } \\
\text { initials }\end{array}$} & \multirow{4}{*}{$\begin{array}{c}\text { Player } \\
\text { position }\end{array}$} & \multicolumn{14}{|c|}{ Total goals scored } \\
\hline & & & & & & & & & \multicolumn{4}{|c|}{ Test } & \multirow{2}{*}{\multicolumn{2}{|c|}{$3 \times 3 \times 3$}} & & \\
\hline & & & \multicolumn{2}{|c|}{ Matches } & \multicolumn{2}{|c|}{$2 \times 2$} & \multicolumn{2}{|c|}{$3 \times 3$} & & & & $\mathrm{x} 2$ & & & \multicolumn{2}{|c|}{$4 \times 4 \times 4$} \\
\hline & & & $1 \mathrm{st} \mathrm{leg}$ & 2nd leg & $\mathrm{I}$ & $\mathrm{F}$ & $\mathrm{I}$ & $\mathrm{F}$ & $\mathrm{I}$ & $\mathrm{F}$ & I & $\mathrm{F}$ & $\mathrm{I}$ & $\mathrm{F}$ & $\mathrm{I}$ & $\mathrm{F}$ \\
\hline 1 & F.M. & GK & 0 & 1 & 1 & 2 & 1 & 1 & 0 & 1 & 1 & 2 & 1 & 1 & 0 & 0 \\
\hline 2 & M.S.M. & IR & 11 & 20 & 4 & 7 & 3 & 3 & 3 & 3 & 3 & 3 & 2 & 3 & 2 & 2 \\
\hline 3 & S.A. & IL & 112 & 113 & 5 & 8 & 5 & 7 & 4 & 5 & 4 & 5 & 4 & 4 & 3 & 4 \\
\hline 4 & B.A. & IR & 4 & 1 & 4 & 5 & 3 & 3 & 2 & 2 & 3 & 3 & 1 & 2 & 1 & 2 \\
\hline 5 & D.A. & $\mathrm{C}$ & 50 & 39 & 4 & 4 & 4 & 3 & 2 & 2 & 2 & 3 & 1 & 2 & 2 & 2 \\
\hline 6 & T.A. & GK & 5 & 0 & 3 & 3 & 2 & 3 & 1 & 0 & 2 & 2 & 1 & 2 & 0 & 1 \\
\hline 7 & C.I. & LW & 0 & 0 & 2 & 4 & 2 & 3 & 1 & 1 & 2 & 2 & 1 & 2 & 0 & 1 \\
\hline 8 & D.M. & LW & 23 & 23 & 4 & 4 & 3 & 4 & 2 & 2 & 2 & 3 & 1 & 2 & 1 & 1 \\
\hline 9 & P.A. & $\mathrm{RW}$ & 3 & 10 & 3 & 4 & 4 & 3 & 2 & 2 & 3 & 4 & 1 & 1 & 1 & 2 \\
\hline 10 & V.T. & $\mathrm{RW}$ & 2 & 16 & 4 & 5 & 4 & 4 & 2 & 2 & 2 & 2 & 2 & 3 & 2 & 2 \\
\hline 11 & P.L. & GK & 51 & 57 & 4 & 5 & 2 & 3 & 2 & 2 & 2 & 3 & 2 & 1 & 2 & 2 \\
\hline 12 & H.S. & GK & 7 & 3 & 4 & 4 & 2 & 2 & 1 & 0 & 2 & 3 & 1 & 2 & 1 & 1 \\
\hline
\end{tabular}

Table 4 shows the results recorded for the indicator "total number of goals scored in the National Junior Championship III in the two-legged matches", as well as in tests. In order to evaluate the performance of players according to the established evaluation scale, we can measure their performance according to the obtained data.

The player Ş.A. is the only one who has "very good" grades in most tests, in both the initial and final tests. If we refer to the goals scored in official matches, this player scored the most goals: 1st leg - 112 goals, 2nd leg - 113 goals. So, we can consider that good performance in the tests indicates the athlete's ability to play in official matches. Also, if we refer to the number of goals scored during tests and matches, we notice that players' results are similar.

Table 5. Results of central tendency parameters for the "goals scored" indicator

\begin{tabular}{|c|c|c|c|c|c|c|c|c|c|c|c|c|c|c|}
\hline \multirow{2}{*}{$\begin{array}{c}\text { Central } \\
\text { tendency } \\
\text { parameters }\end{array}$} & \multicolumn{2}{|c|}{ Matches } & \multicolumn{2}{|c|}{$2 \times 2$} & \multicolumn{2}{|c|}{$3 \times 3$} & \multicolumn{2}{|c|}{$4 \times 4$} & \multicolumn{2}{|c|}{$2 \times 2 \times 2$} & \multicolumn{2}{|c|}{$3 \times 3 \times 3$} & \multicolumn{2}{|c|}{$4 \times 4 \times 4$} \\
\hline & 1 st leg & 2nd leg & Initial & Final & Initial & Final & Initial & Final & Initial & Final & Initial & Final & Initial & Final \\
\hline Mean & 22.33 & 23.58 & 3.50 & 4.58 & 2.92 & 3.25 & 1.83 & 1.83 & 2.33 & 2.92 & 1.50 & 2.08 & 1.25 & 1.67 \\
\hline $\begin{array}{l}\text { Std. Error of } \\
\text { Mean }\end{array}$ & 9.69 & 9.59 & 0.31 & 0.46 & 0.33 & 0.41 & 0.29 & 0.38 & 0.22 & 0.26 & 0.26 & 0.26 & 0.27 & 0.28 \\
\hline Median & $6.00^{\mathrm{a}}$ & $13.00^{\mathrm{a}}$ & $3.67^{\mathrm{a}}$ & $4.38^{\mathrm{a}}$ & $2.86^{\mathrm{a}}$ & $3.11^{\mathrm{a}}$ & $1.78^{\mathrm{a}}$ & $1.75^{\mathrm{a}}$ & $2,30^{\mathrm{a}}$ & $2,80^{\mathrm{a}}$ & $1,36^{\mathrm{a}}$ & $2,00^{\mathrm{a}}$ & $1,25^{\mathrm{a}}$ & $1,60^{\mathrm{a}}$ \\
\hline Mode & 0 & $0^{\mathrm{c}}$ & 4 & 4 & 2 & 3 & 2 & 2 & 2 & 3 & 1 & 2 & $1^{\mathrm{c}}$ & 2 \\
\hline \multicolumn{14}{|l|}{ Deviation } & 0.98 \\
\hline Variance & 1128.42 & 1105.53 & 1.18 & 2.62 & 1.35 & 2.02 & 1.06 & 1.78 & 0.60 & 0.81 & 0.81 & 0.81 & 0.93 & 0.97 \\
\hline Skewness & 2.04 & 2.06 & -1.27 & 0.81 & 0.18 & 1.52 & 0.38 & 0.90 & 0.66 & 1.08 & 2.21 & 0.71 & 0.13 & 0.81 \\
\hline $\begin{array}{l}\text { Std. Error of } \\
\text { Skewness }\end{array}$ & 0.63 & 0.63 & 0.63 & 0.63 & 0.63 & 0.63 & 0.63 & 0.63 & 0.63 & 0.63 & 0.63 & 0.63 & 0.63 & 0.63 \\
\hline Kurtosis & 4.25 & 4.55 & 1.57 & 1.02 & -0.6 & 4.68 & 1.09 & 2.17 & 0.92 & 1.49 & 5.32 & 0.53 & -0.7 & 2.37 \\
\hline $\begin{array}{l}\text { Std. Error of } \\
\text { Kurtosis }\end{array}$ & 1.23 & 1.23 & 1.23 & 1.23 & 1.23 & 1.23 & 1.23 & 1.23 & 1.23 & 1.23 & 1.23 & 1.23 & 1.23 & 1.23 \\
\hline Range & 112 & 113 & 4 & 6 & 4 & 6 & 4 & 5 & 3 & 3 & 3 & 3 & 3 & 4 \\
\hline Minimum & 0 & 0 & 1 & 2 & 1 & 1 & 0 & 0 & 1 & 2 & 1 & 1 & 0 & 0 \\
\hline Maximum & 112 & 113 & 5 & 8 & 5 & 7 & 4 & 5 & 4 & 5 & 4 & 4 & 3 & 4 \\
\hline Sum & 268 & 283 & 42 & 55 & 35 & 39 & 22 & 22 & 28 & 35 & 18 & 25 & 15 & 20 \\
\hline $\mathrm{t}$-Test & \multicolumn{2}{|c|}{-0.632} & \multicolumn{2}{|c|}{-3.463} & & & 0.000 & & & & -3.023 & & & \\
\hline
\end{tabular}


For the "goals scored" indicator (Table 5), the obtained values show a statistically significant improvement in the following tests: in the $2 \times 2$ test, an increase from an average of 3.5 to 4.58 , the calculated t-value is $(-3.463)$, and the $p$-value is less than $0.05(\mathrm{p}=0.005)$; in the $2 \times 2 \times 2$ test, the average 2.33 has increased to 2.93 , the calculated t-value is (-3.924), and the $\mathrm{p}$-value is less than $0.05(\mathrm{p}=0.002)$; in the $3 \times 3 \times 3$ test, the average has increased from 1.5 to 2.08 , the calculated t-value is $(-3.023)$, and the $\mathrm{p}$-value is much below $0.05(\mathrm{p}=0.012)$; in the $4 \times 4 \times 4$ test, the average has increased from 1.23 to 1.67 , the calculated t-value is ($2.803)$, and the $\mathrm{p}$-value is less than $0.05(\mathrm{p}=0.017)$.

b. The "individual tactical actions" indicator

The number of individual tactical actions performed by the players was recorded. The results of central tendency parameters can be observed in Table 6 .

Table 6. Results of central tendency parameters for the "individual tactical actions" indicator

\begin{tabular}{|c|c|c|c|c|c|c|c|c|c|c|c|c|c|c|}
\hline \multirow{2}{*}{$\begin{array}{c}\text { Central } \\
\text { tendency } \\
\text { parameters }\end{array}$} & \multicolumn{2}{|c|}{ Matches } & \multicolumn{2}{|c|}{$2 \times 2$} & \multicolumn{2}{|c|}{$3 \times 3$} & \multicolumn{2}{|c|}{$4 \times 4$} & \multicolumn{2}{|c|}{$2 \times 2 \times 2$} & \multicolumn{2}{|c|}{$3 \times 3 \times 3$} & \multicolumn{2}{|c|}{$4 \times 4 \times 4$} \\
\hline & $1 \mathrm{st} \mathrm{leg}$ & 2nd leg & Initial & Final & Initial & Final & Initial & Final & Initial & Final & Initial & Final & Initial & Final \\
\hline Mean & 12.75 & 13.58 & 1.92 & 2.33 & 1.92 & 2.33 & 1.33 & 1.17 & 2.58 & 2.08 & 1.75 & 1.67 & 1.67 & 1.58 \\
\hline $\begin{array}{l}\text { Std. Error of } \\
\text { Mean }\end{array}$ & 4.70 & 4.90 & 0.22 & 0.33 & 0.28 & 0.33 & 0.25 & 0.29 & 0.14 & 0.19 & 0.17 & 0.14 & 0.18 & 0.19 \\
\hline Median & $6.50^{\mathrm{a}}$ & $10.00^{\mathrm{a}}$ & $1.82^{\mathrm{a}}$ & $2.25^{\mathrm{a}}$ & $1.78^{\mathrm{a}}$ & $2.13^{\mathrm{a}}$ & $1.33^{\mathrm{a}}$ & $1.14^{\mathrm{a}}$ & $2,58^{\mathrm{a}}$ & $2,10^{\mathrm{a}}$ & $1,73^{\mathrm{a}}$ & $1,67^{\mathrm{a}}$ & $1.73^{\mathrm{a}}$ & $1,64^{\mathrm{a}}$ \\
\hline Mode & 3 & $2^{\mathrm{d}}$ & 2 & $2^{d}$ & 1 & 2 & 1 & $0^{\mathrm{d}}$ & 3 & 2 & 2 & 2 & 2 & 2 \\
\hline \multicolumn{14}{|l|}{ Deviation } & 0.66 \\
\hline Variance & 265.47 & 288.26 & 0.62 & 1.33 & 0.99 & 1.33 & 0.78 & 1.06 & 0.26 & 0.44 & 0.38 & 0.24 & 0.42 & 0.44 \\
\hline Skewness & 2.01 & 2.25 & 1.47 & 0.91 & 0.85 & 1.33 & 0.13 & 0.21 & -0.3 & -0.0 & 0.17 & -0.8 & -1.9 & -1.4 \\
\hline $\begin{array}{l}\text { Std. Error of } \\
\text { Skewness }\end{array}$ & 0.63 & 0.63 & 0.63 & 0.63 & 0.63 & 0.63 & 0.63 & 0.63 & 0.63 & 0.63 & 0.63 & 0.63 & 0.63 & 0.63 \\
\hline Kurtosis & 4.21 & 5.82 & 4.31 & 1.36 & -0.0 & 1.71 & -0.2 & -1.1 & -2.2 & -0.1 & -0.0 & -1.6 & 3.16 & 1.38 \\
\hline $\begin{array}{l}\text { Std. Error of } \\
\text { Kurtosis }\end{array}$ & 1.23 & 1.23 & 1.23 & 1.23 & 1.23 & 1.23 & 1.23 & 1.23 & 1.23 & 1.23 & 1.23 & 1.23 & 1.23 & 1.23 \\
\hline Range & 56 & 61 & 3 & 4 & 3 & 4 & 3 & 3 & 1 & 2 & 2 & 1 & 2 & 2 \\
\hline Minimum & 0 & 0 & 1 & 1 & 1 & 1 & 0 & 0 & 2 & 1 & 1 & 1 & 0 & 0 \\
\hline Maximum & 56 & 61 & 4 & 5 & 4 & 5 & 3 & 3 & 3 & 3 & 3 & 2 & 2 & 2 \\
\hline Sum & 153 & 163 & 23 & 28 & 23 & 28 & 16 & 14 & 31 & 25 & 21 & 20 & 20 & 19 \\
\hline t-Test & \multicolumn{2}{|c|}{-0.772} & \multicolumn{2}{|c|}{-2.159} & \multicolumn{2}{|c|}{-1.332} & \multicolumn{2}{|c|}{1.000} & \multicolumn{2}{|c|}{1.915} & \multicolumn{2}{|c|}{0.364} & \multicolumn{2}{|c|}{0.561} \\
\hline
\end{tabular}

For the "individual tactical actions" indicator, the obtained values show a statistically significant improvement in the $2 \times 2$ test, from an average of 1.92 to 2.33 , the calculated tvalue is (-2.159), and the p-value is 0.054 .

c. The "collective tactical actions" indicator

During the sports training, tactical combinations close to the game were used between players. In order to observe how these were used, we recorded the number of collective tactical actions performed by the players. The central tendency parameters can be seen in Table 7 . 
Table 7. Results of central tendency parameters for the "collective tactical actions" indicator

\begin{tabular}{|c|c|c|c|c|c|c|c|c|c|c|c|c|c|c|}
\hline \multirow{2}{*}{$\begin{array}{c}\text { Central } \\
\text { tendency } \\
\text { parameters }\end{array}$} & \multicolumn{2}{|c|}{ Matches } & \multicolumn{2}{|c|}{$2 \times 2$} & \multicolumn{2}{|c|}{$3 \times 3$} & \multicolumn{2}{|c|}{$4 \times 4$} & \multicolumn{2}{|c|}{$2 \times 2 \times 2$} & \multicolumn{2}{|c|}{$3 \times 3 \times 3$} & \multicolumn{2}{|c|}{$4 \times 4 \times 4$} \\
\hline & 1 st leg & 2nd leg & Initial & Final & Initial & Final & Initial & Final & Initial & Final & Initial & Final & Initial & Final \\
\hline Mean & 13.92 & 12.75 & 1.92 & 2.67 & 1.50 & 1.92 & 1.17 & 1.08 & 2.42 & 2.83 & 1.08 & 1.83 & 0.92 & 1.17 \\
\hline $\begin{array}{l}\text { Std. Error of } \\
\text { Mean }\end{array}$ & 4.714 & 4.154 & 0.229 & 0.333 & 0.195 & 0.288 & 0.207 & 0.288 & 0.193 & 0.167 & 0.288 & 0.207 & 0.149 & 0.167 \\
\hline Median & $8.33^{\mathrm{a}}$ & $6.50^{\mathrm{a}}$ & $1.89^{\mathrm{a}}$ & $2.63^{\mathrm{a}}$ & $1.45^{\mathrm{a}}$ & $2.00^{\mathrm{a}}$ & $1.20^{\mathrm{a}}$ & $.90^{\mathrm{a}}$ & $2.45^{\mathrm{a}}$ & $2.82^{\mathrm{a}}$ & $1.00^{\mathrm{a}}$ & $1.80^{\mathrm{a}}$ & $.91^{\mathrm{a}}$ & $1.18^{\mathrm{a}}$ \\
\hline Mode & $5^{d}$ & $0^{\mathrm{d}}$ & 2 & 3 & 1 & $2^{\mathrm{d}}$ & 1 & 1 & 3 & 3 & $0^{\mathrm{d}}$ & 2 & 1 & 1 \\
\hline \multicolumn{14}{|l|}{ Deviation } & 0.577 \\
\hline Variance & 266.629 & 207.114 & 0.629 & 1.333 & 0.455 & 0.992 & 0.515 & 0.992 & 0.447 & 0.333 & 0.992 & 0.515 & 0.265 & 0.333 \\
\hline Skewness & 1.811 & 1.464 & 0.161 & 0.362 & 1.068 & -0.4 & -0.2 & 1.133 & -0.7 & -0.0 & 0.470 & 0.262 & -0.2 & 0.063 \\
\hline $\begin{array}{l}\text { Std. Error of } \\
\text { Skewness }\end{array}$ & 0.637 & 0.637 & 0.637 & 0.637 & 0.637 & 0.637 & 0.637 & 0.637 & 0.637 & 0.637 & 0.637 & 0.637 & 0.637 & 0.637 \\
\hline Kurtosis & 3.388 & 1.691 & -1.261 & 0.300 & 0.352 & -0.6 & -0.6 & 0.946 & -0.1 & 0.655 & -0.6 & -0.6 & 2.220 & 0.655 \\
\hline $\begin{array}{l}\text { Std. Error of } \\
\text { Kurtosis }\end{array}$ & 1.232 & 1.232 & 1.232 & 1.232 & 1.232 & 1.232 & 1.232 & 1.232 & 1.232 & 1.232 & 1.232 & 1.232 & 1.232 & 1.232 \\
\hline Range & 56 & 47 & 2 & 4 & 2 & 3 & 2 & 3 & 2 & 2 & 3 & 2 & 2 & 2 \\
\hline Minimum & 0 & 0 & 1 & 1 & 1 & 0 & 0 & 0 & 1 & 2 & 0 & 1 & 0 & 0 \\
\hline Maximum & 56 & 47 & 3 & 5 & 3 & 3 & 2 & 3 & 3 & 4 & 3 & 3 & 2 & 2 \\
\hline Sum & 167 & 153 & 23 & 32 & 18 & 23 & 14 & 13 & 29 & 34 & 13 & 22 & 11 & 14 \\
\hline t-Test & $\begin{array}{l}0 \\
0\end{array}$ & & $\begin{array}{l}-3 . \\
0 .\end{array}$ & & $\begin{array}{c}-1 . \\
0 .\end{array}$ & & & & & & & & & \\
\hline
\end{tabular}

For the "collective tactical actions" indicator, the obtained values show a statistically significant improvement in the following tests: in the $2 \times 2$ test, an increase from an average of 1.92 to 2.67 , the calculated t-value is $(-3.447)$, and the $\mathrm{p}$-value is less than $0.05(\mathrm{p}=0.005)$; in the $3 \times 3 \times 3$ test, the average has increased from 1.08 to 1.83 , the calculated t-value is $(-2691)$, and the $\mathrm{p}$-value is less than $0.05(\mathrm{p}=0.021)$.

$\mathrm{d}$. The "counterattack actions" indicator

Scoring counterattack goals is considered to be easy. We recorded the number of counterattack actions performed by the players to determine whether this attack phase was used. The recordings were made in official matches and the first three tests (Table 8).

Table 8. Results of central tendency parameters for the "counterattack actions" indicator

\begin{tabular}{|c|c|c|c|c|c|c|c|c|}
\hline \multirow[b]{2}{*}{ Central tendency parameters } & \multicolumn{2}{|c|}{ Matches } & \multicolumn{2}{|c|}{$2 \times 2$} & \multicolumn{2}{|c|}{$3 \times 3$} & \multicolumn{2}{|c|}{$4 \times 4$} \\
\hline & 1 st leg & 2nd leg & Initial & Final & Initial & Final & Initial & Final \\
\hline Mean & 6.83 & 7.67 & 1.50 & 1.67 & 1.25 & 0.50 & 0.50 & 0.50 \\
\hline Std. Error of Mean & 3.282 & 3.838 & 0.359 & 0.333 & 0.305 & 0.151 & 0.230 & 0.230 \\
\hline Median & $2.67^{\mathrm{a}}$ & $3.43^{\mathrm{a}}$ & $1.43^{\mathrm{a}}$ & $1.63^{\mathrm{a}}$ & $1.14^{\mathrm{a}}$ & $.50^{\mathrm{a}}$ & $.40^{\mathrm{a}}$ & $.40^{\mathrm{a}}$ \\
\hline Mode & 0 & 0 & 2 & 2 & 1 & $0^{\mathrm{d}}$ & 0 & 0 \\
\hline Std. Deviation & 11.368 & 13.296 & 1.243 & 1.155 & 1.055 & 0.522 & 0.798 & 0.798 \\
\hline Variance & 129.242 & 176.788 & 1.545 & 1.333 & 1.114 & 0.273 & 0.636 & 0.636 \\
\hline Skewness & 2.453 & 2.528 & 0.511 & 0.362 & 0.522 & 0.000 & 1.289 & 1.289 \\
\hline Std. Error of Skewness & 0.637 & 0.637 & 0.637 & 0.637 & 0.637 & 0.637 & 0.637 & 0.637 \\
\hline Kurtosis & 6.313 & 6.999 & -0.09 & 0.300 & -0.63 & -2.44 & 0.150 & 0.150 \\
\hline Std. Error of Kurtosis & 1.232 & 1.232 & 1.232 & 1.232 & 1.232 & 1.232 & 1.232 & 1.232 \\
\hline Range & 39 & 46 & 4 & 4 & 3 & 1 & 2 & 2 \\
\hline Minimum & 0 & 0 & 0 & 0 & 0 & 0 & 0 & 0 \\
\hline Maximum & 39 & 46 & 4 & 4 & 3 & 1 & 2 & 2 \\
\hline Sum & 82 & 92 & 18 & 20 & 15 & 6 & 6 & 6 \\
\hline t-Test & & & & & & & & \\
\hline
\end{tabular}

For the "counterattack actions" indicator, the obtained values show a statistically significant decrease in counterattack actions in the $3 \times 3$ test, from an average of 1.50 to 0.50 , the calculated $\mathrm{t}$-value is (3.447), and the $\mathrm{p}$-value is less than $0.05(\mathrm{p}=0.005)$.

From the recordings, we can see that there are counterattack actions performed mainly by wingers or pivots. The team needs to improve its attack phase. In order to achieve this, it is 
necessary to improve the defence system and work with the goalkeeper so that the team does not receive goals.

e. The "decisive passes" indicator

We recorded the number of decisive passes made by the players (Table 9).

Table 9. Results of central tendency parameters for the "decisive passes" indicator

\begin{tabular}{|c|c|c|c|c|c|c|c|c|c|c|c|c|c|c|}
\hline \multirow{2}{*}{$\begin{array}{c}\text { Central } \\
\text { tendency } \\
\text { parameters }\end{array}$} & \multicolumn{2}{|c|}{ Matches } & \multicolumn{2}{|c|}{$2 \times 2$} & \multicolumn{2}{|c|}{$3 \times 3$} & \multicolumn{2}{|c|}{$4 \times 4$} & \multicolumn{2}{|c|}{$2 \times 2 \times 2$} & \multicolumn{2}{|c|}{$3 \times 3 \times 3$} & \multicolumn{2}{|c|}{$4 \times 4 \times 4$} \\
\hline & $1 \mathrm{st}$ leg & 2nd leg & Initial & Final & Initial & Final & Initial & Final & Initial & Final & Initial & Final & Initial & Final \\
\hline Mean & 32.17 & 31.42 & 2.92 & 4.33 & 2.67 & 3.00 & 1.58 & 1.42 & 2.33 & 2.92 & 1.67 & 2.08 & 1.25 & 1.67 \\
\hline $\begin{array}{l}\text { Std. Error of } \\
\text { Mean }\end{array}$ & 13.118 & 11.549 & 0.313 & 0.527 & 0.142 & 0.213 & 0.193 & 0.149 & 0.225 & 0.260 & 0.142 & 0.229 & 0.351 & 0.333 \\
\hline Median & $11.00^{\mathrm{a}}$ & $14.50^{\mathrm{a}}$ & $2.88^{\mathrm{a}}$ & $3.86^{\mathrm{a}}$ & $2.67^{\mathrm{a}}$ & $3.00^{\mathrm{a}}$ & $1.55^{\mathrm{a}}$ & $1.42^{\mathrm{a}}$ & $2.30^{\mathrm{a}}$ & $2.80^{\mathrm{a}}$ & $1.67^{\mathrm{a}}$ & $2.00^{\mathrm{a}}$ & $1.00^{\mathrm{a}}$ & $1.45^{\mathrm{a}}$ \\
\hline $\begin{array}{l}\text { Mode } \\
\text { Std. } \\
\text { Deviation }\end{array}$ & $\begin{array}{c}0^{\mathrm{b}} \\
45.441\end{array}$ & $\begin{array}{c}3^{\text {b }} \\
40.008\end{array}$ & $\begin{array}{c}3 \\
1.084\end{array}$ & $\begin{array}{c}3 \\
1.826\end{array}$ & $\begin{array}{c}3 \\
0.492\end{array}$ & $\begin{array}{c}3 \\
0.739\end{array}$ & $\begin{array}{c}1 \\
0.669\end{array}$ & $\begin{array}{c}1 \\
0.515\end{array}$ & $\begin{array}{c}2 \\
0.778\end{array}$ & $\begin{array}{c}3 \\
0.900\end{array}$ & $\begin{array}{c}2 \\
0.492\end{array}$ & $\begin{array}{c}2 \\
0.793\end{array}$ & $\begin{array}{c}1 \\
1.215\end{array}$ & $\begin{array}{c}1 \\
1.155\end{array}$ \\
\hline Variance & 2064.879 & 1600.629 & 1.174 & 3.333 & 0.242 & 0.545 & 0.447 & 0.265 & 0.606 & 0.811 & 0.242 & 0.629 & 1.477 & 1.333 \\
\hline Skewness & 1.657 & 1.629 & 0.192 & 0.912 & -0.812 & 0.000 & 0.735 & 0.388 & 0.668 & 1.082 & -0.812 & 1.152 & 3.076 & 2.488 \\
\hline $\begin{array}{l}\text { Std. Error of } \\
\text { Skewness }\end{array}$ & 0.637 & 0.637 & 0.637 & 0.637 & 0.637 & 0.637 & 0.637 & 0.637 & 0.637 & 0.637 & 0.637 & 0.637 & 0.637 & 0.637 \\
\hline Kurtosis & 2.185 & 1.997 & 0.219 & -0.0 & -1.6 & -0.8 & -0.1 & -2.2 & 0.924 & 1.492 & -1.6 & 2.725 & 10.425 & 7.036 \\
\hline $\begin{array}{l}\text { Std. Error of } \\
\text { Kurtosis }\end{array}$ & 1.232 & 1.232 & 1.232 & 1.232 & 1.232 & 1.232 & 1.232 & 1.232 & 1.232 & 1.232 & 1.232 & 1.232 & 1.232 & 1.232 \\
\hline Range & 143 & 125 & 4 & 6 & 1 & 2 & 2 & 1 & 3 & 3 & 1 & 3 & 5 & 4 \\
\hline Minimum & 0 & 3 & 1 & 2 & 2 & 2 & 1 & 1 & 1 & 2 & 1 & 1 & 0 & 1 \\
\hline Maximum & 143 & 128 & 5 & 8 & 3 & 4 & 3 & 2 & 4 & 5 & 2 & 4 & 5 & 5 \\
\hline Sum & 386 & 377 & 35 & 52 & 32 & 36 & 19 & 17 & 28 & 35 & 20 & 25 & 15 & 20 \\
\hline t-Test & ( & & $\begin{array}{c}-3 \\
0\end{array}$ & & $\begin{array}{c}-2 \\
0\end{array}$ & & $\begin{array}{l}1 . \\
0 .\end{array}$ & & $\begin{array}{r}-3 \\
0 .\end{array}$ & & $\begin{array}{c}-2 \\
0\end{array}$ & & & \\
\hline
\end{tabular}

For the "decisive passes" indicator, the obtained values show a statistically significant improvement in the following tests: in the $2 \times 2$ test, an increase from an average of 2.92 to 4.33 , the calculated $\mathrm{t}$-value is $(-3.261)$, and the $\mathrm{p}$-value is less than $0.05(\mathrm{p}=0.008)$; in the $3 \mathrm{x}$ 3 test, an increase from an average of 2.67 to 3 , the calculated t-value is (-2.345), and the pvalue is less than $0.05(\mathrm{p}=0.039)$; in the $2 \times 2 \times 2$ test, the average has increased from 2.33 to 2.92 , the calculated $\mathrm{t}$-value is $(-3.924)$, and the $\mathrm{p}$-value is less than $0.05(\mathrm{p}=0.002)$; in the $3 \mathrm{x}$ $3 \times 3$ test, the average has increased from 1.67 to 2.08 , the calculated t-value is $(-2.159)$, and the p-value is 0.054; in the $4 \times 4 \times 4$ test, the average has increased from 1.25 to 1.67 , the calculated $t$-value is $(-2.803)$, and the $p$-value is less than $0.05(p=0.017)$.

$\mathrm{f}$. The indicator "ball recovery in the defence phase through an individual tactical action" In the defence phase, the number of balls recovered by the players through an individual tactical action was recorded (Table 10). 
Table 10. Results of central tendency parameters for the indicator "ball recovery in the defence phase through an individual tactical action"

\begin{tabular}{|c|c|c|c|c|c|c|c|c|c|c|c|c|c|c|}
\hline \multirow{2}{*}{$\begin{array}{c}\text { Central } \\
\text { tendency } \\
\text { parameters }\end{array}$} & \multicolumn{2}{|c|}{ Matches } & \multicolumn{2}{|c|}{$2 \times 2$} & \multicolumn{2}{|c|}{$3 \times 3$} & \multicolumn{2}{|c|}{$4 \times 4$} & \multicolumn{2}{|c|}{$2 \times 2 \times 2$} & \multicolumn{2}{|c|}{$3 \times 3 \times 3$} & \multicolumn{2}{|c|}{$4 \times 4 \times 4$} \\
\hline & 1st leg & 2nd leg & Initial & Final & Initial & Final & Initial & Final & Initial & Final & Initial & Final & Initial & Final \\
\hline Mean & 7.83 & 9.33 & 0.75 & 1.17 & 0.67 & 0.50 & 0.42 & 0.33 & 0.33 & 0.67 & 0.58 & 0.33 & 0.75 & 1.08 \\
\hline $\begin{array}{l}\text { Std. Error of } \\
\text { Mean }\end{array}$ & 2.208 & 2.709 & 0.131 & 0.167 & 0.188 & 0.151 & 0.149 & 0.142 & 0.142 & 0.188 & 0.149 & 0.142 & 0.131 & 0.260 \\
\hline Median & $7.00^{\mathrm{a}}$ & $7.00^{\mathrm{a}}$ & $.75^{\mathrm{a}}$ & $1.18^{\mathrm{a}}$ & $.64^{\mathrm{a}}$ & $.50^{\mathrm{a}}$ & $.42^{\mathrm{a}}$ & $.33^{\mathrm{a}}$ & $.33^{\mathrm{a}}$ & $.64^{\mathrm{a}}$ & $.58^{\mathrm{a}}$ & $.33^{\mathrm{a}}$ & $.75^{\mathrm{a}}$ & $1.00^{\mathrm{a}}$ \\
\hline Mode & 0 & 0 & 1 & 1 & 1 & $0^{\mathrm{d}}$ & 0 & 0 & 0 & 1 & 1 & 0 & 1 & 1 \\
\hline $\begin{array}{l}\text { Std. } \\
\text { Deviation }\end{array}$ & 7.650 & 9.384 & 0.452 & 0.577 & 0.651 & 0.522 & 0.515 & 0.492 & 0.492 & 0.651 & 0.515 & 0.492 & 0.452 & 0.900 \\
\hline Variance & 58.515 & 88.061 & 0.205 & 0.333 & 0.424 & 0.273 & 0.265 & 0.242 & 0.242 & 0.424 & 0.265 & 0.242 & 0.205 & 0.811 \\
\hline Skewness & 0.479 & 0.558 & -1.327 & 0.063 & 0.439 & 0.000 & 0.388 & 0.812 & 0.812 & 0.439 & -0.3 & 0.812 & -1.3 & 0.712 \\
\hline $\begin{array}{l}\text { Std. Error of } \\
\text { Skewness }\end{array}$ & 0.637 & 0.637 & 0.637 & 0.637 & 0.637 & 0.637 & 0.637 & 0.637 & 0.637 & 0.637 & 0.637 & 0.637 & 0.637 & 0.637 \\
\hline Kurtosis & -1.26 & -1.190 & -0.32 & 0.655 & -0.3 & -2.4 & -2.2 & -1.6 & -1.6 & -0.3 & -2.2 & -1.6 & -0.3 & 0.533 \\
\hline $\begin{array}{l}\text { Std. Error of } \\
\text { Kurtosis }\end{array}$ & 1.232 & 1.232 & 1.232 & 1.232 & 1.232 & 1.232 & 1.232 & 1.232 & 1.232 & 1.232 & 1.232 & 1.232 & 1.232 & 1.232 \\
\hline Range & 20 & 25 & 1 & 2 & 2 & 1 & 1 & 1 & 1 & 2 & 1 & 1 & 1 & 3 \\
\hline Minimum & 0 & 0 & 0 & 0 & 0 & 0 & 0 & 0 & 0 & 0 & 0 & 0 & 0 & 0 \\
\hline Maximum & 20 & 25 & 1 & 2 & 2 & 1 & 1 & 1 & 1 & 2 & 1 & 1 & 1 & 3 \\
\hline Sum & 94 & 112 & 9 & 14 & 8 & 6 & 5 & 4 & 4 & 8 & 7 & 4 & 9 & 13 \\
\hline t-Test & \multicolumn{2}{|c|}{-1.892} & \multicolumn{2}{|c|}{-1.820} & \multicolumn{2}{|c|}{0.692} & \multicolumn{2}{|c|}{0.561} & \multicolumn{2}{|c|}{-1.483} & \multicolumn{2}{|c|}{1.393} & \multicolumn{2}{|c|}{-1.773} \\
\hline
\end{tabular}

For the indicator "ball recovery in the defence phase through an individual tactical action", the obtained values do not show statistically significant improvements in any test.

g. The "goals received in the defence phase" indicator

In order to observe the efficiency of players in the defensive phase, we recorded the number of goals received in the area where they were playing (Table 11).

Table 11. Results of central tendency parameters for the "goals received in the defence phase" indicator

\begin{tabular}{|c|c|c|c|c|c|c|c|c|c|c|c|c|c|c|}
\hline \multirow{2}{*}{$\begin{array}{c}\text { Central } \\
\text { tendency } \\
\text { parameters }\end{array}$} & \multicolumn{2}{|c|}{ Matches } & \multicolumn{2}{|c|}{$2 \times 2$} & \multicolumn{2}{|c|}{$3 \times 3$} & \multicolumn{2}{|c|}{$4 \times 4$} & \multicolumn{2}{|c|}{$2 \times 2 \times 2$} & \multicolumn{2}{|c|}{$3 \times 3 \times 3$} & \multicolumn{2}{|c|}{$4 \times 4 \times 4$} \\
\hline & 1st leg & 2nd leg & Initial & Final & Initial & Final & Initial & Final & Initial & Final & Initial & Final & Initial & Final \\
\hline Mean & 18.83 & 19.75 & 3.33 & 4.75 & 2.92 & 3.25 & 2.00 & 2.08 & 2.33 & 2.75 & 1.83 & 2.25 & 1.17 & 1.67 \\
\hline $\begin{array}{l}\text { Std. Error of } \\
\text { Mean }\end{array}$ & 4.141 & 3.780 & 0.284 & 0.351 & 0.336 & 0.411 & 0.275 & 0.379 & 0.142 & 0.179 & 0.112 & 0.218 & 0.167 & 0.188 \\
\hline Median & $13.67^{\mathrm{a}}$ & $18.00^{\mathrm{a}}$ & $3.38^{\mathrm{a}}$ & $4.56^{\mathrm{a}}$ & $2.86^{\mathrm{a}}$ & $3.11^{\mathrm{a}}$ & $1.89^{\mathrm{a}}$ & $2.00^{\mathrm{a}}$ & $2.33^{\mathrm{a}}$ & $2.73^{\mathrm{a}}$ & $1.83^{\mathrm{a}}$ & $2.30^{\mathrm{a}}$ & $1.18^{\mathrm{a}}$ & $1.64^{\mathrm{a}}$ \\
\hline Mode & 11 & 38 & 4 & 4 & 2 & 3 & 2 & 2 & 2 & 3 & 2 & $2^{\mathrm{d}}$ & 1 & 2 \\
\hline $\begin{array}{l}\text { Std. } \\
\text { Deviation }\end{array}$ & 14.345 & 13.095 & 0.985 & 1.215 & 1.165 & 1.422 & 0.953 & 1.311 & 0.492 & 0.622 & 0.389 & 0.754 & 0.577 & 0.651 \\
\hline Variance & 205.788 & 171.477 & 0.970 & 1.477 & 1.356 & 2.023 & 0.909 & 1.720 & 0.242 & 0.386 & 0.152 & 0.568 & 0.333 & 0.424 \\
\hline Skewness & 0.302 & 0.332 & -0.127 & 0.934 & 0.189 & 1.522 & 0.755 & 0.690 & 0.812 & 0.170 & -2.0 & -0.4 & 0.063 & 0.439 \\
\hline $\begin{array}{l}\text { Std. Error of } \\
\text { Skewness }\end{array}$ & 0.637 & 0.637 & 0.637 & 0.637 & 0.637 & 0.637 & 0.637 & 0.637 & 0.637 & 0.637 & 0.637 & 0.637 & 0.637 & 0.637 \\
\hline Kurtosis & -1.72 & -1.313 & -0.980 & 0.460 & -0.6 & 4.689 & 0.161 & 1.159 & -1.6 & -0.0 & 2.640 & -0.8 & 0.655 & -0.3 \\
\hline $\begin{array}{l}\text { Std. Error of } \\
\text { Kurtosis }\end{array}$ & 1.232 & 1.232 & 1.232 & 1.232 & 1.232 & 1.232 & 1.232 & 1.232 & 1.232 & 1.232 & 1.232 & 1.232 & 1.232 & 1.232 \\
\hline Range & 39 & 36 & 3 & 4 & 4 & 6 & 3 & 5 & 1 & 2 & 1 & 2 & 2 & 2 \\
\hline Minimum & 0 & 2 & 2 & 3 & 1 & 1 & 1 & 0 & 2 & 2 & 1 & 1 & 0 & 1 \\
\hline Maximum & 39 & 38 & 5 & 7 & 5 & 7 & 4 & 5 & 3 & 4 & 2 & 3 & 2 & 3 \\
\hline Sum & 226 & 237 & 40 & 57 & 35 & 39 & 24 & 25 & 28 & 33 & 22 & 27 & 14 & 20 \\
\hline t-Test & $\begin{array}{c}-0 \\
0\end{array}$ & & $\begin{array}{c}-4 . \\
0.6\end{array}$ & & $\begin{array}{c}-1 . \\
0 .\end{array}$ & & $\begin{array}{c}-0 \\
0 .\end{array}$ & & & & & & & \\
\hline
\end{tabular}

For the "goals received in the defence phase" indicator, the obtained values show a statistically significant improvement in the following tests: in the 2 x 2 test, an increase from an average of 3.33 to 4.75 , the calculated t-value is (-4.214), and the p-value is less than 0.05 $(\mathrm{p}=0.001)$; in the $2 \times 2 \times 2$ test, an increase from an average of 2.33 to 2.75 , the calculated $\mathrm{t}-$ value is $(-2.803)$, and the $\mathrm{p}$-value is less than $0.05(\mathrm{p}=0.017)$; in the $3 \times 3 \times 3$ test, the average 
has increased from 1.83 to 2.25 , the calculated t-value is (-2.159), and the p-value is 0.054 ; in the $4 \times 4 \times 4$ test, the average has increased from 1.17 to 1.67 , the calculated t-value is $(-2.569)$, and the $p$-value is less than $0.05(\mathrm{p}=0.026)$.

The increased number of goals received during the tests mentioned above indicates that players need to improve their defence skills.

\section{Discussion}

By comparing both the results obtained in official matches and the results achieved in initial and final tests, we can highlight the following significant increases:

- there were significant increases for the "goals scored" indicator compared to the increase in the number of goals scored by the team under study, but also for the "goals received" indicator, so we can consider that the team needs to improve its defence systems.

- from the presented data, it can be observed that the number and quality of decisive passes were improved in 5 tests; the increases were statistically significant at the 0.05 threshold. We believe that the players have improved their ability to make decisions in a short time and find solutions to pass efficiently.

- there were no statistically significant differences between 1st and 2nd leg matches, which could be attributed to the fact that players had constant performance throughout the competitive period. According to the effort curve and the sports shape of players, we consider it important to maintain their exercise capacity throughout the competitive period, with the possibility for them to reach the sports shape (maximum efficiency) in the most important matches.

\section{Correlations between indicators}

From the results obtained in the two-legged official matches and the initial and final tests, we can observe statistically significant correlations between the following indicators:

a. Goals scored in the two-legged matches and tests and the decisive passes to score a goal

A very strong statistical correlation is observed between the "goals scored in 1st leg" and "goals scored in 2nd leg" indicators recorded in both matches and tests. Tables 12, 13 and 14 show (marked in yellow) all correlations that exceed the 0.69 threshold and highlight that there is a strong correlation between indicators. Correlations exceeding the 0.49 threshold (marked in green) reveal that the correlation is moderate.

Table 12. Correlations between the goals scored during matches and the tests

\begin{tabular}{|c|c|c|c|c|c|c|c|c|c|c|c|c|}
\hline \multirow[b]{2}{*}{ Correlation } & \multicolumn{12}{|c|}{ Total goals scored } \\
\hline & $\begin{array}{c}1 \text { st leg } \\
1\end{array}$ & $\begin{array}{c}\text { 2nd leg } \\
2\end{array}$ & $\begin{array}{c}2 \times 2 \\
\text { Initial }\end{array}$ & $\begin{array}{l}2 \times 2 \\
\text { Final }\end{array}$ & $\begin{array}{c}3 \times 3 \\
\text { Initial }\end{array}$ & $\begin{array}{l}3 \times 3 \\
\text { Final }\end{array}$ & $\begin{array}{c}4 \times 4 \\
\text { Initial }\end{array}$ & $\begin{array}{l}4 \times 4 \\
\text { Final }\end{array}$ & $\begin{array}{c}2 \times 2 \times 2 \\
\text { Final }\end{array}$ & $\begin{array}{c}3 \times 3 \times 3 \\
\text { Initial }\end{array}$ & $\begin{array}{c}4 \times 4 \times 4 \\
\text { Initial }\end{array}$ & $\begin{array}{c}4 \times 4 \times 4 \\
\text { Final }\end{array}$ \\
\hline $\begin{array}{l}\text { Total goals } \\
\text { scored in 1st } \\
\text { leg matches }\end{array}$ & 1 & $.979^{* *}$ & $.592^{*}$ & $.629^{*}$ & 0.554 & $.759^{* *}$ & $.703^{*}$ & $.744^{* *}$ & $.728^{* *}$ & $.796^{* *}$ & $.746^{* *}$ & $.765^{* *}$ \\
\hline $\begin{array}{l}\text { Sig. (2- } \\
\text { tailed) }\end{array}$ & & 0.000 & 0.042 & 0.029 & 0.062 & 0.004 & 0.011 & 0.006 & 0.007 & 0.002 & 0.005 & 0.004 \\
\hline $\begin{array}{l}\text { Total goals } \\
\text { scored in } 2 \text { nd } \\
\text { leg matches }\end{array}$ & $.979^{* *}$ & 1 & $.607^{*}$ & $.706^{*}$ & $.593^{*}$ & $.798^{* *}$ & $.765^{* *}$ & $.816^{* *}$ & $.737^{* *}$ & $.878^{* *}$ & $.811^{* *}$ & $.812^{* *}$ \\
\hline $\begin{array}{l}\text { Sig. (2- } \\
\text { tailed) }\end{array}$ & 0.000 & & 0.036 & 0.010 & 0.042 & 0.002 & 0.004 & 0.001 & 0.006 & 0.000 & 0.001 & 0.001 \\
\hline
\end{tabular}


Table 13. Correlations between the "goals scored during matches" and the "individual tactical actions" indicators

\begin{tabular}{|c|c|c|c|c|c|c|c|c|c|c|c|}
\hline \multirow[b]{2}{*}{ Correlation } & \multicolumn{11}{|c|}{ Total goals scored with individual tactical actions } \\
\hline & $\begin{array}{c}1 \text { st leg } \\
1\end{array}$ & $\begin{array}{c}\text { 2nd leg } \\
2\end{array}$ & $\begin{array}{c}2 \times 2 \\
\text { Initial }\end{array}$ & $\begin{array}{l}2 \times 2 \\
\text { Final }\end{array}$ & $\begin{array}{c}3 \times 3 \\
\text { Initial }\end{array}$ & $\begin{array}{l}3 \times 3 \\
\text { Final }\end{array}$ & $\begin{array}{c}2 \times 2 \times 2 \\
\text { Initial }\end{array}$ & $\begin{array}{c}2 \times 2 \times 2 \\
\text { Final }\end{array}$ & $\begin{array}{c}3 \times 3 \times 3 \\
\text { Initial }\end{array}$ & $\begin{array}{c}4 \times 4 \times 4 \\
\text { Initial }\end{array}$ & $\begin{array}{c}4 \times 4 \times 4 \\
\text { Final }\end{array}$ \\
\hline $\begin{array}{l}\text { Total goals } \\
\text { scored in } 1 \mathrm{st} \\
\text { leg matches }\end{array}$ & $.983^{* *}$ & $.942^{* *}$ & $.703^{*}$ & $.614^{*}$ & $.842^{* *}$ & $.812^{* *}$ & $.628^{*}$ & $.618^{*}$ & $.643^{*}$ & $.657^{*}$ & $.603^{*}$ \\
\hline $\begin{array}{l}\text { Sig. (2- } \\
\text { tailed) }\end{array}$ & 0.000 & 0.000 & 0.011 & 0.034 & 0.001 & 0.001 & 0.029 & 0.032 & 0.024 & 0.020 & 0.038 \\
\hline $\begin{array}{l}\text { Total goals } \\
\text { scored in } 2 \text { nd } \\
\text { leg matches }\end{array}$ & $.955^{* *}$ & $.951^{* *}$ & $.689^{*}$ & $.630^{*}$ & $.829^{* *}$ & $.792^{* *}$ & $.624^{*}$ & $.679^{*}$ & $.709^{* *}$ & $.703^{*}$ & $.645^{*}$ \\
\hline $\begin{array}{l}\text { Sig. (2- } \\
\text { tailed) }\end{array}$ & 0.000 & 0.000 & 0.013 & 0.028 & 0.001 & 0.002 & 0.030 & 0.015 & 0.010 & 0.011 & 0.024 \\
\hline
\end{tabular}

Table 14. Correlations between the goals scored during matches and the "collective tactical actions" and "decisive passes" indicators

\begin{tabular}{|c|c|c|c|c|c|c|c|c|c|c|c|c|c|c|}
\hline \multirow[b]{2}{*}{ Correlation } & \multicolumn{6}{|c|}{ Total goals scored with collective tactical actions } & \multicolumn{8}{|c|}{ Decisive passes } \\
\hline & $\begin{array}{c}1 \text { st leg } \\
1\end{array}$ & $\begin{array}{c}\text { 2nd leg } \\
2\end{array}$ & $\begin{array}{l}4 \times 4 \\
\text { Initial }\end{array}$ & $\begin{array}{c}4 \times 4 \\
F\end{array}$ & $\begin{array}{c}3 \times 3 \\
\times 3 \\
\text { Initial }\end{array}$ & $\begin{array}{c}4 \times 4 \\
\times 4 \\
\text { Initial }\end{array}$ & $\begin{array}{c}1 \text { st leg } \\
1\end{array}$ & $\begin{array}{c}\text { 2nd leg } \\
2\end{array}$ & $\begin{array}{l}3 \times 3 \\
\text { Final }\end{array}$ & $\begin{array}{c}4 \times 4 \\
\text { Initial }\end{array}$ & $\begin{array}{l}4 \times 4 \\
\text { Final }\end{array}$ & $\begin{array}{c}\times 3 \\
\times 3 \\
\text { Final }\end{array}$ & $\begin{array}{c}4 \times 4 \\
\times 4 \\
\text { Initial }\end{array}$ & $\begin{array}{c}4 \times 4 \times \\
4 \\
\text { Final }\end{array}$ \\
\hline $\begin{array}{l}\text { Total goals } \\
\text { scored in } \\
\text { 1st leg } \\
\text { matches }\end{array}$ & $.964^{* *}$ & $.925^{* *}$ & $.632^{*}$ & $.793^{* *}$ & $.582^{*}$ & $.596^{*}$ & $.868^{* *}$ & $.851^{* *}$ & $.638^{*}$ & $.804^{* *}$ & $.664^{*}$ & $.654^{*}$ & $.833^{* *}$ & $.786^{* *}$ \\
\hline $\begin{array}{l}\text { Sig. (2- } \\
\text { tailed) }\end{array}$ & 0.000 & 0.000 & 0.028 & 0.002 & 0.047 & 0.041 & 0.000 & 0.000 & 0.026 & 0.002 & 0.019 & 0.021 & 0.001 & 0.002 \\
\hline $\begin{array}{l}\text { Total goals } \\
\text { scored in } \\
\text { 2nd leg } \\
\text { matches }\end{array}$ & $.926^{* *}$ & $.935^{* *}$ & $.685^{*}$ & $.855^{* *}$ & $.642^{*}$ & $.662^{*}$ & $.856^{* *}$ & $.841^{* *}$ & $.629^{*}$ & $.801^{* *}$ & $.691^{*}$ & $\begin{array}{c}.743^{*} \\
*\end{array}$ & $.851^{* *}$ & $.825^{* *}$ \\
\hline $\begin{array}{l}\text { Sig. (2- } \\
\text { tailed) }\end{array}$ & 0.000 & 0.000 & 0.014 & 0.000 & 0.024 & 0.019 & 0.000 & 0.001 & 0.028 & 0.002 & 0.013 & 0.006 & 0.000 & 0.001 \\
\hline
\end{tabular}

b. Tactical actions performed during official matches and tests

Another correlation that statistically recorded a strong association between indicators was the total number of tactical actions performed in the two-legged matches of the championship (Table 15).

Table 15. Correlations between the total number of tactical actions in the two-legged matches of the championship and the indicators containing the total number of individual and collective tactical actions

\begin{tabular}{|c|c|c|c|c|c|c|c|c|c|c|c|c|}
\hline \multirow{2}{*}{\multicolumn{2}{|c|}{$\begin{array}{c}\text { Indicators } \\
\text { Matches or tests }\end{array}$}} & \multicolumn{5}{|c|}{ Total actions } & \multicolumn{4}{|c|}{ Total individual actions } & \multicolumn{2}{|c|}{$\begin{array}{c}\text { Total collective } \\
\text { actions }\end{array}$} \\
\hline & & 1st leg & 2nd leg & $2 \times 2$ & $4 \times 4$ & $3 \times 3 \times 3$ & $1 \mathrm{st}$ leg & 2nd leg & $2 \times 2$ & $3 \times 3$ & 1 st leg & 2nd leg \\
\hline \multicolumn{2}{|c|}{ 1st leg/2nd leg/Initial/Final } & 1 & 2 & Final & Initial & Initial & 1 & 2 & Initial & Initial & 1 & 2 \\
\hline \multirow{2}{*}{$\begin{array}{l}\text { Total actions } \\
\text { in } 1 \text { st leg } \\
\text { matches }\end{array}$} & $\begin{array}{l}\text { Pearson } \\
\text { Correlation }\end{array}$ & 1 & $.986^{* *}$ & $.718^{* *}$ & $.611^{*}$ & $.605^{*}$ & $.974^{* *}$ & $.935^{* *}$ & $.646^{*}$ & $.729^{* *}$ & $.948^{* *}$ & $.889^{* *}$ \\
\hline & $\begin{array}{l}\text { Sig. }(2- \\
\text { tailed) }\end{array}$ & & 0.000 & 0.009 & 0.035 & 0.037 & 0.000 & 0.000 & 0.023 & 0.007 & 0.000 & 0.000 \\
\hline \multirow{2}{*}{$\begin{array}{l}\text { Total actions } \\
\text { in } 2 \text { nd leg } \\
\text { matches }\end{array}$} & $\begin{array}{l}\text { Pearson } \\
\text { Correlation }\end{array}$ & $.986^{* *}$ & 1 & $.730^{* *}$ & $.680^{*}$ & $.623^{*}$ & $.957^{* *}$ & $.944^{* *}$ & $.592^{*}$ & $.678^{*}$ & $.924^{* *}$ & $.906^{* *}$ \\
\hline & $\begin{array}{l}\text { Sig. (2- } \\
\text { tailed) }\end{array}$ & 0.000 & & 0.007 & 0.015 & 0.030 & 0.000 & 0.000 & 0.043 & 0.015 & 0.000 & 0.000 \\
\hline
\end{tabular}

c. Individual tactical actions performed during official matches and tests

Another correlation that statistically recorded a strong data association was established between the total number of individual tactical actions performed in the two-legged matches of the championship (Tables 16 and 17). 
Table 16. Correlations between the total number of individual tactical actions in the twolegged matches of the championship and the total number of tactical actions

\begin{tabular}{|c|c|c|c|c|c|c|c|c|c|}
\hline \multirow{2}{*}{\multicolumn{2}{|c|}{$\begin{array}{c}\text { Indicators } \\
\text { Matches or tests }\end{array}$}} & \multicolumn{8}{|c|}{ Total actions } \\
\hline & & \multirow{2}{*}{$\begin{array}{c}1 \text { st leg } \\
1\end{array}$} & \multirow{2}{*}{$\begin{array}{c}\text { 2nd leg } \\
2\end{array}$} & \multirow{2}{*}{$\begin{array}{l}2 \times 2 \\
\text { Initial }\end{array}$} & \multirow{2}{*}{$\begin{array}{l}2 \times 2 \\
\text { Final } \\
\end{array}$} & \multirow{2}{*}{$\begin{array}{l}4 \times 4 \\
\text { Initial }\end{array}$} & \multirow{2}{*}{$\begin{array}{l}4 \times 4 \\
\text { Final }\end{array}$} & \multirow{2}{*}{$\begin{array}{c}2 \times 2 \times 2 \\
\text { Initial }\end{array}$} & \multirow{2}{*}{$\begin{array}{c}3 \times 3 \times 3 \\
\text { Initial }\end{array}$} \\
\hline $1 \mathrm{st} \mathrm{leg} / 2 \mathrm{nd} \mathrm{l}$ & itial/Final & & & & & & & & \\
\hline $\begin{array}{l}\text { Total individual } \\
\text { actions in } 1 \mathrm{st} \text { leg }\end{array}$ & $\begin{array}{l}\text { Pearson } \\
\text { Correlation }\end{array}$ & $.974^{* * *}$ & $.957^{* *}$ & $.616^{*}$ & $.630^{*}$ & $.632^{*}$ & 0.538 & 0.523 & 0.565 \\
\hline matches & Sig. (2-tailed) & 0.000 & 0.000 & 0.033 & 0.028 & 0.027 & 0.071 & 0.081 & 0.056 \\
\hline $\begin{array}{l}\text { Total individual } \\
\text { actions in } 2 \text { nd leg }\end{array}$ & $\begin{array}{l}\text { Pearson } \\
\text { Correlation }\end{array}$ & $.935^{* *}$ & $.944^{* *}$ & 0.547 & $.588^{*}$ & $.629^{*}$ & $.602^{*}$ & $.590^{*}$ & $.604^{*}$ \\
\hline matches & Sig. (2-tailed) & 0.000 & 0.000 & 0.066 & 0.044 & 0.028 & 0.038 & 0.043 & 0.038 \\
\hline
\end{tabular}

Table 17. Correlations between the total number of individual tactical actions in the twolegged matches of the championship and the individual and collective actions

\begin{tabular}{|c|c|c|c|c|c|c|c|c|c|c|}
\hline \multirow{2}{*}{\multicolumn{2}{|c|}{$\begin{array}{c}\text { Indicators } \\
\text { Matches or tests }\end{array}$}} & \multicolumn{6}{|c|}{ Total individual actions } & \multicolumn{3}{|c|}{ Total collective actions } \\
\hline & & \multirow{2}{*}{$\begin{array}{c}1 \text { st leg } \\
1\end{array}$} & \multirow{2}{*}{$\begin{array}{c}\text { 2nd leg } \\
2 \\
976^{* *}\end{array}$} & \multirow{3}{*}{$\begin{array}{l}2 \times 2 \\
\text { Initial } \\
.709^{* *}\end{array}$} & \multirow{3}{*}{$\begin{array}{l}2 \times 2 \\
\text { Final } \\
.618^{*}\end{array}$} & \multirow{3}{*}{$\begin{array}{l}3 \times 3 \\
\text { Initial } \\
.743^{* *}\end{array}$} & \multirow{3}{*}{$\begin{array}{l}3 \times 3 \\
\text { Final } \\
.623^{*}\end{array}$} & \multirow{3}{*}{$\begin{array}{c}\text { 1st leg } \\
1 \\
.938^{* *}\end{array}$} & \multirow{3}{*}{$\begin{array}{c}\text { 2nd leg } \\
2 \\
.880^{* *}\end{array}$} & \multirow{3}{*}{$\begin{array}{l}4 \times 4 \\
\text { Final } \\
.617^{*}\end{array}$} \\
\hline 1st leg/2nd le & Initial/Final & & & & & & & & & \\
\hline $\begin{array}{l}\text { Total individual } \\
\text { actions in 1st }\end{array}$ & & 1 & & & & & & & & \\
\hline leg matches & Sig. & & 0.000 & 0.0 & 0.0 & 0.0 & 0.0 & 0.00 & 0.000 & 0.032 \\
\hline $\begin{array}{l}\text { Total individual } \\
\text { actions in } 2 \text { nd }\end{array}$ & $\begin{array}{l}\text { Pearson } \\
\text { Correlation }\end{array}$ & $.976^{* *}$ & 1 & $.679^{*}$ & $.629^{*}$ & $.686^{*}$ & $.736^{* *}$ & $.903^{* *}$ & $.863^{* *}$ & $.663^{*}$ \\
\hline leg matches & Sig. (2-tailed) & 0.000 & & 0.015 & 0.028 & 0.014 & 0.006 & 0.000 & 0.000 & 0.019 \\
\hline
\end{tabular}

d. Collective tactical actions performed during official matches and tests

A strong correlation from a statistical point of view was also recorded between the total number of collective tactical actions performed in the two-legged matches of the championship (Tables 18 and 19).

Table 18. Correlations between the total number of collective tactical actions in the two-legged matches of the championship and the total number of tactical actions

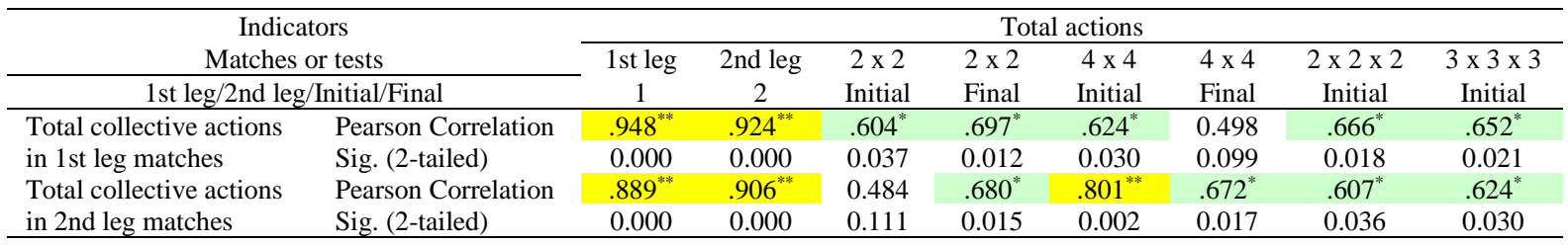

Table 19. Correlations between the total number of collective tactical actions in the two-legged matches of the championship and the individual and collective actions

\begin{tabular}{|c|c|c|c|c|c|c|c|c|c|c|c|}
\hline \multirow{2}{*}{\multicolumn{2}{|c|}{$\begin{array}{c}\text { Indicators } \\
\text { Matches or tests }\end{array}$}} & \multicolumn{6}{|c|}{ Total individual actions } & \multicolumn{4}{|c|}{ Total collective actions } \\
\hline & & $1 \mathrm{st}$ leg & 2nd leg & $2 \times 2$ & $2 \times 2$ & $3 \times 3$ & $3 \times 3$ & $1 \mathrm{st}$ leg & 2nd leg & $4 \times 4$ & $3 \times 3 \times 3$ \\
\hline \multicolumn{2}{|c|}{ 1st leg/2nd leg/Initial/Final } & 1 & 2 & Initial & Final & Initial & Final & 1 & 2 & Final & Initial \\
\hline \multirow{4}{*}{$\begin{array}{l}\text { Total } \\
\text { collective } \\
\text { actions in 1st } \\
\text { leg matches } \\
\text { Total } \\
\text { collective } \\
\text { actions in } 2 \text { nd } \\
\text { leg matches }\end{array}$} & $\begin{array}{l}\text { Pearson } \\
\text { Correlation }\end{array}$ & $.938^{* *}$ & $.903^{* *}$ & $.723^{* *}$ & $.701^{*}$ & $.793^{* *}$ & $.604^{*}$ & 1 & $.951^{* *}$ & $.716^{* *}$ & 0.565 \\
\hline & $\begin{array}{l}\text { Sig. (2- } \\
\text { tailed) }\end{array}$ & 0.000 & 0.000 & 0.008 & 0.011 & 0.002 & 0.037 & & 0.000 & 0.009 & 0.056 \\
\hline & $\begin{array}{l}\text { Pearson } \\
\text { Correlation }\end{array}$ & $.880^{* *}$ & $.863^{* *}$ & $.667^{*}$ & $.667^{*}$ & $.715^{* *}$ & 0.547 & $.951^{* *}$ & 1 & $.839^{* *}$ & $.585^{*}$ \\
\hline & $\begin{array}{l}\text { Sig. }(2- \\
\text { tailed) }\end{array}$ & 0.000 & 0.000 & 0.018 & 0.018 & 0.009 & 0.066 & 0.000 & & 0.001 & 0.046 \\
\hline
\end{tabular}




\section{Conclusion}

After the application of small-sided games as a means of preparation and evaluation, the favourable results obtained lead us to say that these means of training can improve the performance of players during official matches. Within the statistical analysis, significant results were noted regarding the correlation between the indicators recorded during matches and tests. Statistical calculations have shown that there is a significant correlation between the number of goals scored in official matches and the goals scored in individual tactical actions and collective tactical actions, and the goals scored during tests. Also, a strong correlation was highlighted between the goals scored and the decisive passes, and between various actions in which the goal was scored, as opposed to the total number of individual or collective actions.

The training period for players between the initial and final tests was about 3 months. We consider that the obtained results provide useful information that should be taken into account, given that the period was short and the players were not all at the same level of training. However, their progress can be seen in certain indicators such as the higher number of goals scored or the higher number of decisive passes. The constant development of individual and collective tactical actions is noted. It is also observed that several goals were received in defence and no significant values were recorded for the ball recovery in defence.

The recordings during matches, according to the values of statistical indicators, revealed that the two-legged games of the championship did not show significant differences. We consider that, in a team sport for junior III training level, it is quite difficult to maintain the sports shape at a constant level and increase the team's value/ quality of the game from one stage to another. However, we highlight that, at this age, the players from ACS Sporting Ghimbav did not have major fluctuations in the game, managing to keep the team's play constant throughout the competition.

Based on the obtained results, we can say that small-sided games are an efficient category of means of training and evaluation of the technical and tactical content acquired by junior handball players.

\section{Authors' Contributions}

Both authors have equally contributed to this study and should be considered as main authors.

\section{References}

Balint, E. (2005). Instruirea în jocul de handbal: Conținut tactic [Handball training: Tactical content]. Brașov: Editura Universității Transilvania.

Bilge, M. (2012). Game analysis of Olympic, World and European Championships in men's handball. Journal of Human Kinetics, 35, 109-118. https://doi.org/10.2478/v10078-012-0084-7

Bota, I. (1984). Handbal: Modele de joc și pregătire [Handball: Game and training models]. București: Sport-Turism.

Cercel, P. (1983). Handbal: Antrenamentul echipelor masculine [Handball: Men's team training]. București: Sport-Turism. 
Cercel, P. (1980). Handbal: Exerciții pentru fazele de joc [Handball: Exercises for the game phases]. București: Sport-Turism.

European Handball Federation. (2019a). Cumulative statistics. Romania: Women's 19 EHF Euro 2019, Gyor/Hungary.

http://home.eurohandball.com/ehf_files/specificHBI/ECh_Analyses/2019/HUN/2/1/05.Ro mania.pdf

European Handball Federation. (2019b). Cumulative team statistics Romania 2019 Women's 17 EHF EURO - Final Round, Slovenia, Celje.

http://home.eurohandball.com/ehf_files/specificHBI/ECh_Analyses/2019/SLO/1/FINAL \%20ROUND\%20W17\%20SLO.pdf

European Handball Federation. (2018). Cumulative statistics. Romania: 13th Women's EHF Euro 2018 - Final Round, France.

http://home.eurohandball.com/ehf_files/specificHBI/ECh_Analyses/2018/FRA/1/Final\%2 ORound.pdf

Federația Română de Handbal. (2017). Regulament de desfășurare a campionatului național: Mini handbal feminin-masculin, an competitional 2017-2018 [Rules for the national championship: Women's and men's mini handball, 2017-2018 competitive year]. București: FRH. http://www.frh.ro/frh/pdf/regulamente/minihandbal.pdf

Ghermănescu, I. K. (1983). Teoria și metodica handbalului [Handball: Theory and methodology]. București: Editura Didactică și Pedagogică.

González-Víllora, S., García-López, L. M., \& Contreras-Jordán, O. R. (2015). Decision making and skill development in youth football players. Revista Internacional de Medicina y Ciencias de la Actividad Física y el Deporte, 15(59), 467-487. https://doi.org/10.15366/rimcafd2015.59.005

Gutiérrez, D., Fisette, J., García-López, L. M., \& Contreras, O. (2014). Assessment of secondary school students' game performance related to tactical contexts. Journal of Human Kinetics, 42, 223-234. https://doi.org/10.2478/hukin-2014-0076

Ghobadi, H., Rajabi, H., Farzad, B., Bayati, M., \& Jeffreys, I. (2013). Anthropometry of worldclass elite handball players according to the playing position: Reports from Men's Handball World Championship 2013. Journal of Human Kinetics, 39, 213-220. https://dx.doi.org/10.2478\%2Fhukin-2013-0084

Hantău, C. (2017). Minihandbal: Stadiul I al instruirii în handbal [Mini handball: Stage 1 of handball training]. București: Printech.

Hortiguela Alcalá, D. H., \& Hernando Garijo, A. (2017). Teaching Games for Understanding: A comprehensive approach to promote student's motivation in physical education. Journal of Human Kinetics, 59, 17-27. https://dx.doi.org/10.1515\%2Fhukin-2017-0144

Igorov-Bosi, M., Hantău, C., \& Caracaş, V. (2004). Fundamente științifice ale jocurilor sportive: Handbal - Curs universitar [Scientific foundations of sports games: Handball University textbook]. București: Bren.

Korte, F., \& Lames, M. (2019). Passing network analysis of positional attack formations in handball. Journal of Human Kinetics, 70, 209-221. https://dx.doi.org/10.2478\%2Fhukin-2019-0044

Milanović, D., Vuleta, D., \& Ohnjec, K. (2018). Performance indicators of winning and defeated female handball teams in matches of the 2012 Olympic Games Tournament. Journal of Human Kinetics, 64, 247-253. https://dx.doi.org/10.1515\%2Fhukin-2017-0198

Pic, M. (2018). Performance and home advantage in handball. Journal of Human Kinetics, 63, 61-71. https://dx.doi.org/10.2478\%2Fhukin-2018-0007

Priklerová, S. (2018). Effects of conditioning programme on the changes of motor performance in youth categories in handball. Acta Facultatis Educationis Physicae Universitatis Comenianae, 58(2). https://doi.org/10.2478/afepuc-2018-0012 
Serrien, B., \& Baeyens, J.-P. (2018). Systematic review and meta-analysis on proximal-todistal sequencing in team handball: Prospects for talent detection? Journal of Human Kinetics, 63(1), 9-21. https://doi.org/10.2478/hukin-2018-0002

Sotiriu, R. (1998). Handbal: Antrenament - teorie - metodică [Handball: Training - theory methodology]. București: Gapola.

Urbán, T., Gutiérrez, O, \& Moreno, F. J. (2015). Effects of unstable conditions on kinematics and performance variables in young handball players. Journal of Human Kinetics, 46, 3948. https://doi.org/10.1515/hukin-2015-0032

Wagner, H., Finkenzeller, T., Würth, S., \& von Duvillard, S. P. (2014). Individual and team performance in team-handball: A review. Journal of Sports Science and Medicine, 13(4), 808-816. https://pubmed.ncbi.nlm.nih.gov/25435773/

Wagner, H., Orwat, M., Hinz, M., Pfusterschimed, J., Bacharach, D. W., Duvillard, S. P., \& Muller, E. (2016). Testing game-based performance in team-handball. Journal of Strength and Conditioning Research, 30(10), 2794-280.

https://doi.org/10.1519/jsc.0000000000000580 